\title{
Legacy source of mercury in an urban stream-wetland ecosystem in central North Carolina, USA
}

\author{
Amrika Deonarine ${ }^{\mathrm{a}, *}$, Heileen Hsu-Kim ${ }^{\mathrm{a}}$, Tong Zhang ${ }^{\mathrm{a}, 1}$, Yong Cai ${ }^{\mathrm{b}}$, Curtis J. Richardson ${ }^{\mathrm{c}}$ \\ ${ }^{a}$ Duke University, Department of Civil and Environmental Engineering, Box 90287, Durham, NC 27708, USA \\ ${ }^{\mathrm{b}}$ Florida International University, Department of Chemistry and Biochemistry, Miami, Fl 33199, USA \\ ' Duke University Wetland Center, Nicholas School of the Environment, Box 90333, Durham, NC 27708, USA
}

\section{H I G H L I G H T S}

- Runoff collected from university catchment is discharged to a stream-wetland ecosystem.

- Hg concentrations documented in water, soil, and sediment samples.

- Phenylmercury and methylmercury detected in soil and sediments.

- Phenylmercury historically used as an anti-fungal agent, e.g., in seed treatment.

- Historically used $\mathrm{Hg}$ compounds could be a source of non-point $\mathrm{Hg}$ to watersheds.

\section{A R T I C L E I N F O}

\section{Article history:}

Received 14 August 2014

Received in revised form 26 November 2014

Accepted 12 December 2014

Available online 7 January 2015

Handling Editor: X. Cao

\section{Keywords:}

Mercury

Methylmercury

Phenylmercury

Urban runoff

Fungicide

Wetland

\begin{abstract}
A B S T R A C T
In the United States, aquatic mercury contamination originates from point and non-point sources to watersheds. Here, we studied the contribution of mercury in urban runoff derived from historically contaminated soils and the subsequent production of methylmercury in a stream-wetland complex (Durham, North Carolina), the receiving water of this runoff. Our results demonstrated that the mercury originated from the leachate of grass-covered athletic fields. A fraction of mercury in this soil existed as phenylmercury, suggesting that mercurial anti-fungal compounds were historically applied to this soil. Further downstream in the anaerobic sediments of the stream-wetland complex, a fraction (up to 9\%) of mercury was converted to methylmercury, the bioaccumulative form of the metal. Importantly, the concentrations of total mercury and methylmercury were reduced to background levels within the streamwetland complex. Overall, this work provides an example of a legacy source of mercury that should be considered in urban watershed models and watershed management.
\end{abstract}

(c) 2014 Elsevier Ltd. All rights reserved.

\section{Introduction}

Urban watersheds in the United States (US) are often impaired by excess contaminants from the surrounding landscape, including trace metals such as mercury ( $\mathrm{Hg}$ ). $\mathrm{Hg}$ has been identified as one of the leading causes of impairment to water bodies in the US (US EPA, 2004), and is of particular concern due to the potential for formation of methylmercury (MeHg), a bioaccumulative neurotoxin.

Sources of $\mathrm{Hg}$ to urban watersheds include industrial and municipal point source discharges and non-point sources such as atmospheric deposition and surface runoff. Point sources are regulated

\footnotetext{
* Corresponding author. Tel.: +1 (919) 3089104.

E-mail address: amrikadeonarine@gmail.com (A. Deonarine).

1 Present address: Woods Hole Oceanographic Institution, Department of Marine Chemistry and Geochemistry, 266 Woods Hole Rd., Woods Hole, MA 02543, USA.
}

in the US under the Clean Water Act (1972) using the National Pollutant Discharge Eliminating System and Total Maximum Daily Load (TMDL) approaches for discharges to waterbodies while non-point sources are currently addressed using TMDLs only. The TMDL approach determines the $\mathrm{Hg}$ loading that is required at the watershed scale so that water quality standards are satisfied and beneficial uses of the watershed are protected. This includes determining target $\mathrm{Hg}$ concentrations in biota and water bodies, identifying $\mathrm{Hg}$ sources and loadings, and implementing programs to reduce $\mathrm{Hg}$ loading to the watershed. However, non-point $\mathrm{Hg}$ sources are difficult to monitor and control due to their diffuse nature, and the current regulatory approach can be hampered by limited data on $\mathrm{Hg}$ and $\mathrm{MeHg}$ sources in impaired regions.

The US Environmental Protection Agency (US EPA) has estimated that compared to point sources, non-point pollutant sources are now significant contributors to impaired waters in the US (US 
EPA a). Direct deposition of atmospheric $\mathrm{Hg}$ is considered to be a major non-point source, accounting for up to $40-60 \%$ of the total Hg loading in some areas (Sorensen et al., 1990; Fitzgerald et al., 1991). The recent US EPA Mercury and Air Toxics Standards (2011) regulates atmospheric $\mathrm{Hg}$ emissions from coal-fired power plants, effectively reducing the major source of $\mathrm{Hg}$ to the atmosphere in the US (US EPA d). However, Hg loadings to waterbodies from surface runoff remain difficult to address. Surface runoff is typically generated in large volumes in urban areas due to the high percentage of impervious land cover that prevents infiltration to groundwater. In addition to atmospheric $\mathrm{Hg}$ deposition, sources of $\mathrm{Hg}$ to runoff include leachates from construction material, dust, soils and waste materials. The extent and relative contribution of these sources vary widely and depend on factors such as geographic location, and current and historic land use practices. $\mathrm{Hg}$ from these sources can be mobilized during precipitation events and transported via runoff to water bodies where $\mathrm{MeHg}$ production can take place (Krabbenhoft et al., 1995; Driscoll et al., 1998).

In this study, we documented $\mathrm{Hg}$ contamination in soil and runoff originating from turf sod and developed landscapes from a section of the Duke University campus during minimal flow. This runoff feeds directly into a restored stream-wetland ecosystem complex where we also investigated $\mathrm{MeHg}$ production, as wetlands can provide conditions suitable for $\mathrm{Hg}$ methylation.

\section{Materials and methods}

\subsection{Study site}

The focus of our study is a campus catchment that includes impervious surfaces such as buildings, and grassy surfaces such as landscaping and athletic fields. Surface runoff from precipitation and irrigation within this catchment is collected via catch basins that are drained by underground pipes (Mahi, 1994), and is continuously discharged into an open channel stream tributary feeding into Sandy Creek (Fig. 1).

Sandy Creek drains part of the Duke University campus (Durham, North Carolina, US) and subsequently feeds into Jordan Lake, a regional drinking water supply reservoir which forms the headwaters of the Cape Fear River Basin. Urban activity resulting in altered stormwater delivery and stream bank erosion has led to inadequate hydrologic functions of Sandy Creek, including its capacity to retain nutrient and sediment loadings (Richardson et al., 2011). Duke University established the Stream and Wetland Assessment Management Park (SWAMP) (Richardson et al., 2011) (Fig. 1) to improve the water quality of Sandy Creek by creating surface flow wetland bioretention ponds to sequester excess nutrients in campus runoff, re-contouring of the main stem of the Sandy Creek stream bed to improve hydraulic connectivity with the flood plain, and constructing a dam and reservoir for stormwater retention (Fig. 1). These measures were implemented to restore hydrologic function, to allow natural biogeochemical and sedimentation processes to occur, and to dampen large storm event flows downstream, and were completed in 2007 (Richardson et al., 2011).

\subsection{Field sampling}

Twelve sampling locations were selected along the underground stormwater system on campus (S1, S2, S3 and S4), the stream tributary (T1, T2, T3, T4 and T5), and main stem of Sandy Creek (C1, C2 and C3) (Fig. 1). Water, soil, and sediment were sampled in September 2008, April 2009 and August 2009, and locations S1-S4 were also sampled as part of a preliminary assessment in
March 2008. Samples were collected under baseline flow conditions (defined as two or more days without rainfall preceding the sampling event), as $\mathrm{Hg}$ sources to runoff and not $\mathrm{Hg}$ transport dynamics were the focus of this study. Thus, the flow rate measured during the sampling period is due to irrigation. At sites S1S4, water samples were obtained via manhole access to the catch basins where runoff is collected. Soil was collected from above ground within a $1 \mathrm{~m}$ radius of the catch basin, except for Site S2, where the closest soil was obtained $\sim 5 \mathrm{~m}$ away. Soil samples were collected from the top 3-5 cm of soil beneath the grass layer. In the stream tributary (T1-T5) and main stem of Sandy Creek (C1-C3), surface water and sediment grab samples (top $3-5 \mathrm{~cm}$ ) were collected near the stream banks. Flow rate was estimated using a V-notch weir at site T3 (SI).

Water samples for total $\mathrm{Hg}$ and $\mathrm{MeHg}$ analysis were collected in acid cleaned borosilicate and fluoropolymer bottles according to US EPA standard protocols (US EPA, 1996). Aliquots of water samples were filtered using $0.45 \mu \mathrm{m}$ disposable vacuum filtration units with cellulose acetate filter membranes (Fisher Scientific). Water samples, including blanks, were preserved with $0.5 \%(\mathrm{v} / \mathrm{v})$ bromine monochloride for total $\mathrm{Hg}$ analysis (US EPA, 2002) and $0.2 \%(\mathrm{v} / \mathrm{v})$ hydrochloric acid for MeHg analysis (US EPA, 1998) and stored at $4{ }^{\circ} \mathrm{C}$. Soil and sediment samples were collected in polypropylene centrifuge tubes and stored at $-15^{\circ} \mathrm{C}$. All samples were collected in duplicate or triplicate.

\subsection{Water and soil analyses}

Total $\mathrm{Hg}$ and total filterable $\mathrm{Hg}$ were quantified in water samples by stannous chloride reduction, gold amalgamation and cold vapor atomic fluorescence spectrometry (Bloom and Fitzgerald, 1988; US EPA, 2002). Precision and recovery checks were performed using a Trace Certified Mercury in Water reference (Fluka-Sigma Aldrich) (SI Table S1). Particulate Hg was calculated as the difference between total $\mathrm{Hg}$ and total filterable $\mathrm{Hg}$. Bromide was quantified by ion chromatography (ICS-2000, Dionex) and total solids was quantified by standard methods (Standard Methods 2540 B) (Eaton et al., 2005).

In soil and sediment samples, total $\mathrm{Hg}$ was quantified by thermal decomposition, amalgamation and atomic absorption spectrometry (DMA 80, Milestone) (US EPA, 1998), and was validated using a certified reference material for Trace Elements in Soil (National Institute of Standards and Technology, USA) (SI Table S1). MeHg was quantified using acid-dichloromethane leaching and aqueous back extraction, followed by ethylation, pyrolysis and cold vapor atomic absorption spectrometry (Bloom et al., 1997; US EPA, 1998) (SI). An aliquot of reference material Total and Methylmercury in Estuarine Sediment (Institute for Reference Materials and Measurements, Belgium) was analyzed in parallel with each batch of sediment samples. Data was accepted only for certified reference material recoveries from approximately $70 \%$ to 100\% (SI Table S1) (US EPA, 1998).

Phenylmercury was measured by acid-dichloromethane leaching, aqueous phase extraction, and high performance liquid chromatography coupled with atomic fluorescence spectrometry (Hintelmann and Wilken, 1993) (SI). Acid volatile sulfide (AVS) was measured using acid leaching, volatilization of hydrogen sulfide and subsequent trapping in sodium hydroxide, followed by colorimetric detection by the Cline method (Cline, 1969; Allen et al., 1993). While sediment samples were frozen immediately upon return to the laboratory after collection, the samples were thawed overnight under oxic laboratory conditions, possibly resulting in loss of some sulfide. Therefore, the AVS data are considered semi-quantitative. 


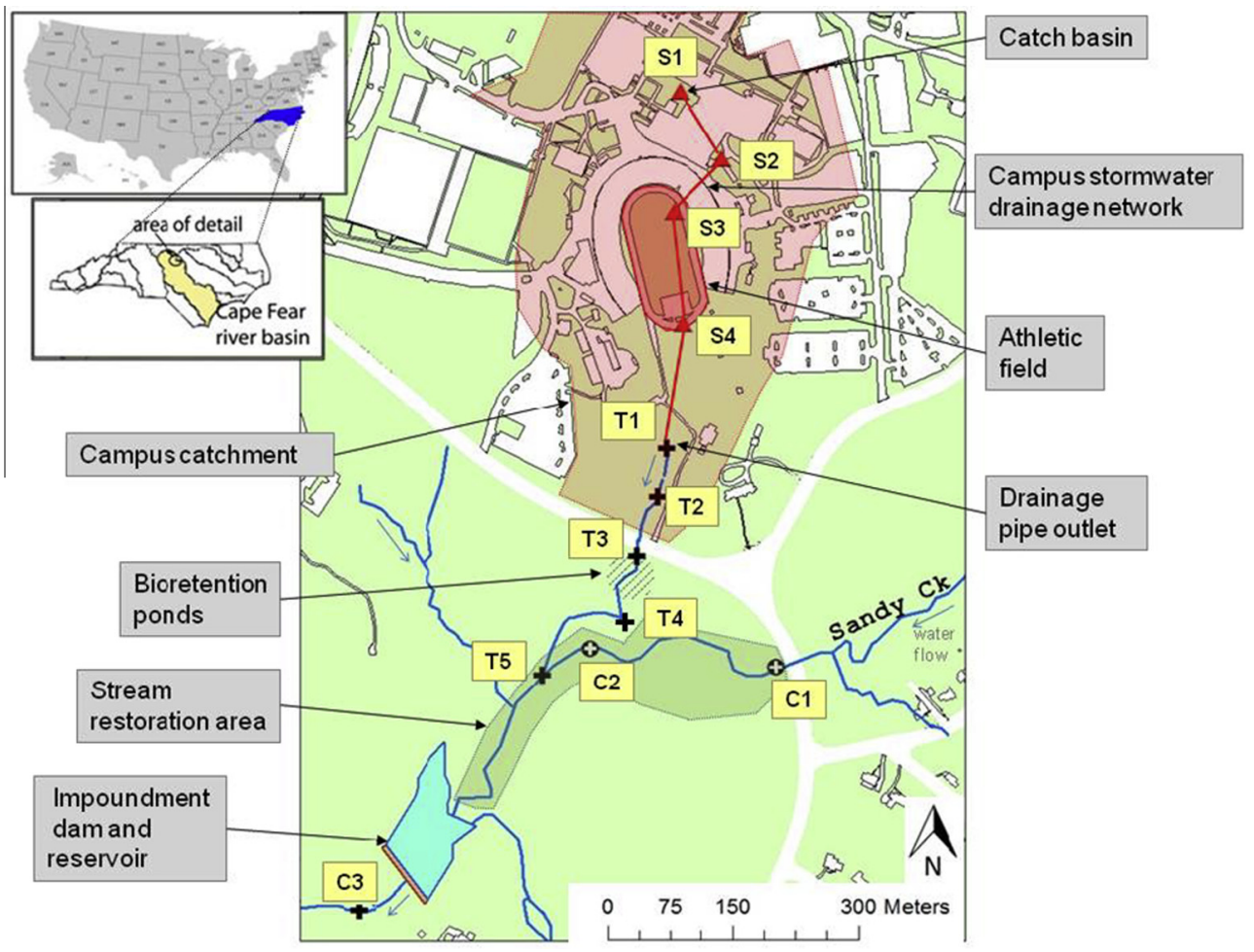

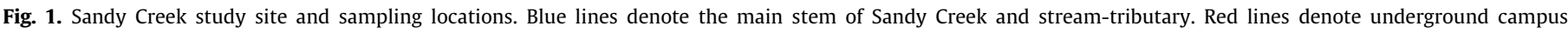

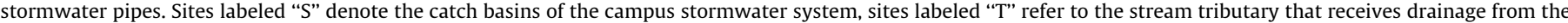

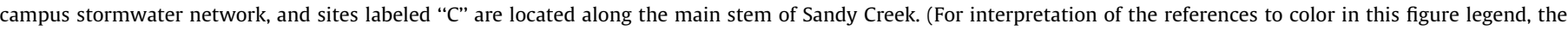
reader is referred to the web version of this article.)

\section{Results and discussion}

\subsection{Total $\mathrm{Hg}$ in campus soil and runoff}

Within the campus catchment, total $\mathrm{Hg}$ concentrations in unfiltered water samples at sites S3 and S4 were consistently one to two orders of magnitude higher $\left(110-254 \mathrm{ng} \mathrm{L}^{-1}\right)$ compared to upstream values (3.5-12.3 $\mathrm{ng} \mathrm{L}^{-1}$ at $\mathrm{S} 1, \mathrm{~S} 2$ and $\leqslant 2.4 \mathrm{ng} \mathrm{L}^{-1}$ at $\mathrm{C} 1$, C2) (Fig. 1). An analysis of variance (ANOVA) performed on the normalized square root-transformed data indicated that $\mathrm{Hg}$ concentrations at sites S3 and S4 were statistically different from background sites S1 and S2 ( $p<0.05, F=127.5)$. Downstream of sites S3 and S4, total $\mathrm{Hg}$ decreased with distance to $38-116 \mathrm{ng} \mathrm{L}^{-1}$ at the drainage pipe outlet (T1), and $6.6 \mathrm{ng} \mathrm{L}^{-1}$ at the furthest downstream location (C3). This data suggested that there was a source of $\mathrm{Hg}$ to the drainage water at sites S3 and S4, both located on the athletic field. A small fraction of the total $\mathrm{Hg}(<23 \%)$ was quantified in the dissolved fraction $(<0.45 \mu \mathrm{m})$ at site $\mathrm{S} 3$, indicating that the majority of $\mathrm{Hg}$ was associated with particulate material such as dust, soil, and resuspended sediment particles (SI Fig. S1). This is consistent with data on $\mathrm{Hg}$ in urban runoff from previous studies, where $\mathrm{Hg}$ was largely associated with suspended particulate material (Eckley and Branfireun, 2008; Brigham et al., 2009).

Total $\mathrm{Hg}$ in soils within the campus catchment was subsequently quantified. The $\mathrm{Hg}$ soil concentration at the furthest upstream site (S1) was $0.04 \pm 0.02 \mu \mathrm{g} \mathrm{g}^{-1}$ (dw) (Fig. 2), comparable to $\mathrm{Hg}$ levels in soils and stream sediments derived from agricultural, suburban and urban areas in the Upper Cape Fear River Basin, NC $\left(0.04 \pm 0.02 \mu \mathrm{g} \mathrm{g}^{-1}(\mathrm{dw})(n=151)\right)$ (US Geological Survey). An ANOVA of the normalized square root-transformed data demonstrated that $\mathrm{Hg}$ concentrations at sites S3 and S4 were significantly higher than background levels at sites S1 and S2 $(p<0.05, F=32.6)$. $\mathrm{Hg}$ soil concentrations at S3 and S4 varied over three orders of

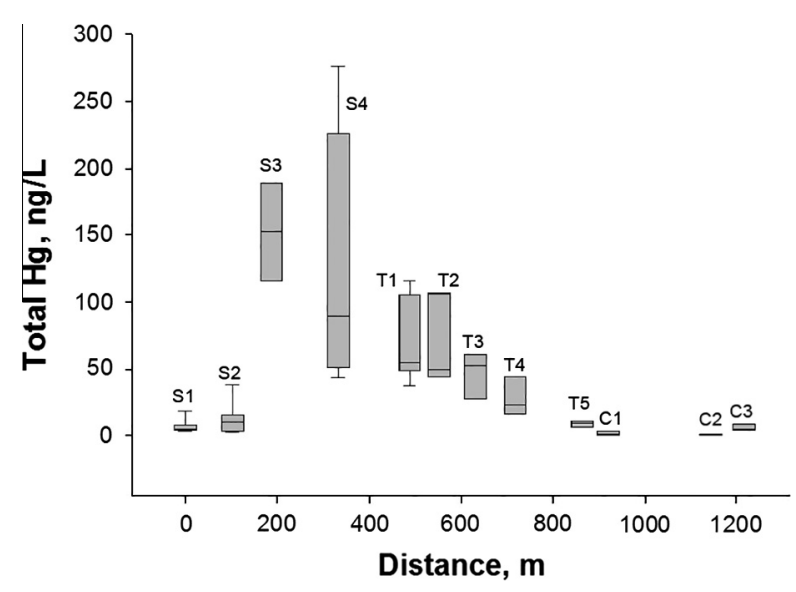

Fig. 2. Total Hg concentrations in drainage (S1-S4) and surface water (T1-C3) for March 2008 to August 2009. Data are plotted as distance from Site S1, using box and whisker plots showing $5-95 \%$ percentile range, median, and $25-75 \%$ percentiles $(n=8-10$ for all sites, except C2 $(n=2)$ and C3 $(n=2))$. All data are included in SI Table S2.

magnitude, from 0.06 to $7.7 \mu \mathrm{g} \mathrm{g}^{-1}$ (dw) ( $n=26$ ), suggesting that there were hotspots of $\mathrm{Hg}$-contaminated soil on the athletic field.

\subsection{Organo-Hg compounds in campus soil}

While atmospheric Hg deposition is known to pervade North Carolina and the eastern US (US EPA, 1997), deposition alone (without a major emissions source nearby) is not enough to explain orders of magnitude variations in $\mathrm{Hg}$ concentrations on the athletic field (S3, S4) and other soils that were less than $200 \mathrm{~m}$ away (S1, S2). To address this question, other potential 
sources of $\mathrm{Hg}$ to the field were identified. Phenylmercury and methylmercury were subsequently quantified in selected soils from the campus catchment, as these compounds were widely used as anti-fungal agents in paints, seed preservatives and fertilizers in the US in the early 1900s and continuing to the 1990s (FAO; US EPA b).

Soil and sediment samples at sites S1, S3, S4, and C3 were analyzed for phenylmercury (Fig. 4a). Phenylmercury was detected in all analyzed samples, with the highest concentrations (14.3-60.2 $\left.\mathrm{ng} \mathrm{g}^{-1}(\mathrm{dw})\right)$ observed at sites S3 and S4 on the athletic field. At these locations, approximately $0.1-2.6 \%$ of the total $\mathrm{Hg}$ was present as phenylmercury. The detection of phenylmercury at the background site (S1) indicated that phenylmercury compounds (e.g., phenylmercury acetate) were also applied to landscaped sections within the campus catchment. Phenylmercury was also detected at the furthest downstream site (C3), suggesting that the phenylmercury may have been transported downstream from the catchment via the mobilization of soil particles.

In addition to phenylmercury, $\mathrm{MeHg}$ concentrations in athletic field soil $\left(0.5-3.0 \mathrm{ng} \mathrm{g}^{-1}(\mathrm{dw}),<1 \%\right.$ of total $\mathrm{Hg}$ ) were slightly elevated relative to soils located upstream ( $\leqslant 1.2 \mathrm{ng} \mathrm{g}^{-1}(\mathrm{dw})$ ) (Fig. 4b). To determine if the source of MeHg was in situ Hg methylation, MeHg concentrations were compared to soil AVS concentrations (SI Fig. S2). AVS was used here as an indicator of sulfate reduction which is often correlated with $\mathrm{MeHg}$ production due to the activity of sulfate reducing bacteria (King et al., 1999). Relatively low AVS concentrations $\left(<0.09 \mu \mathrm{mol} \mathrm{g}^{-1}(\mathrm{dw})\right)$ were detected in soil throughout the campus catchment (S1-S4), suggesting there was little or no in situ MeHg production. A more likely source of $\mathrm{MeHg}$ could be the external application of $\mathrm{MeHg}$ compounds in fertilizers, for example, methylmercury dicyandiamide (Panogen ${ }^{\circledR}$ ) (FAO).

\subsection{Source of $\mathrm{Hg}$ to the athletic field}

A history of the study site that includes complete details of potential $\mathrm{Hg}$ sources, such as materials used for construction and structural fill or Hg-containing fertilizer and grass seed applications, is undocumented. However, the determination of elevated $\mathrm{Hg}$ concentrations in soil on the athletic field and the detection of phenylmercury in field soil samples strongly suggest that one source of $\mathrm{Hg}$ was the historical application of anti-fungal $\mathrm{Hg}$ compounds. Phenylmercury has only been detected in agricultural soils where anti-fungal agents were applied or in areas known to be contaminated by phenylmercury-based fungicides (Sumino,

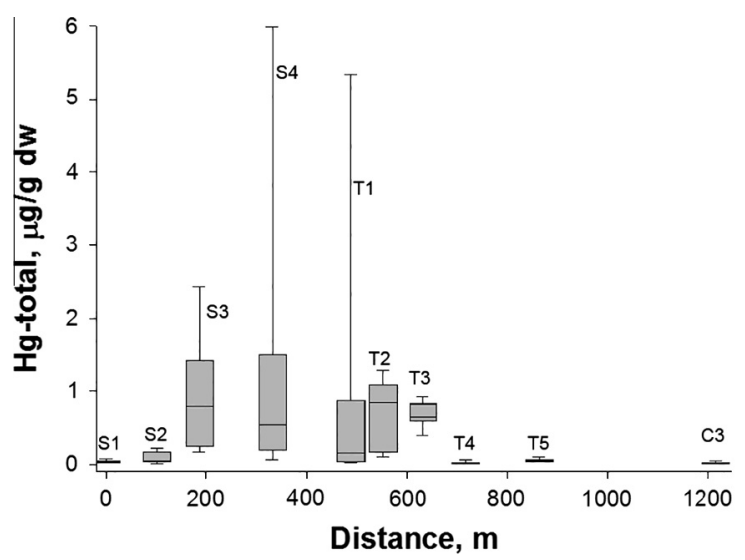

Fig. 3. Total Hg concentrations in soil near catch basins (S1-S4), sediment samples of the stream tributary (T1-T5), and the main stem of Sandy Creek (C3) from March 2008 to August 2009. Data are plotted as a function of distance from site S1, using box and whisker plots showing 5-95\% percentile range, median, and 25-75\% percentiles $(n=8-10)$ for all sites. All data are shown in SI Table S3.
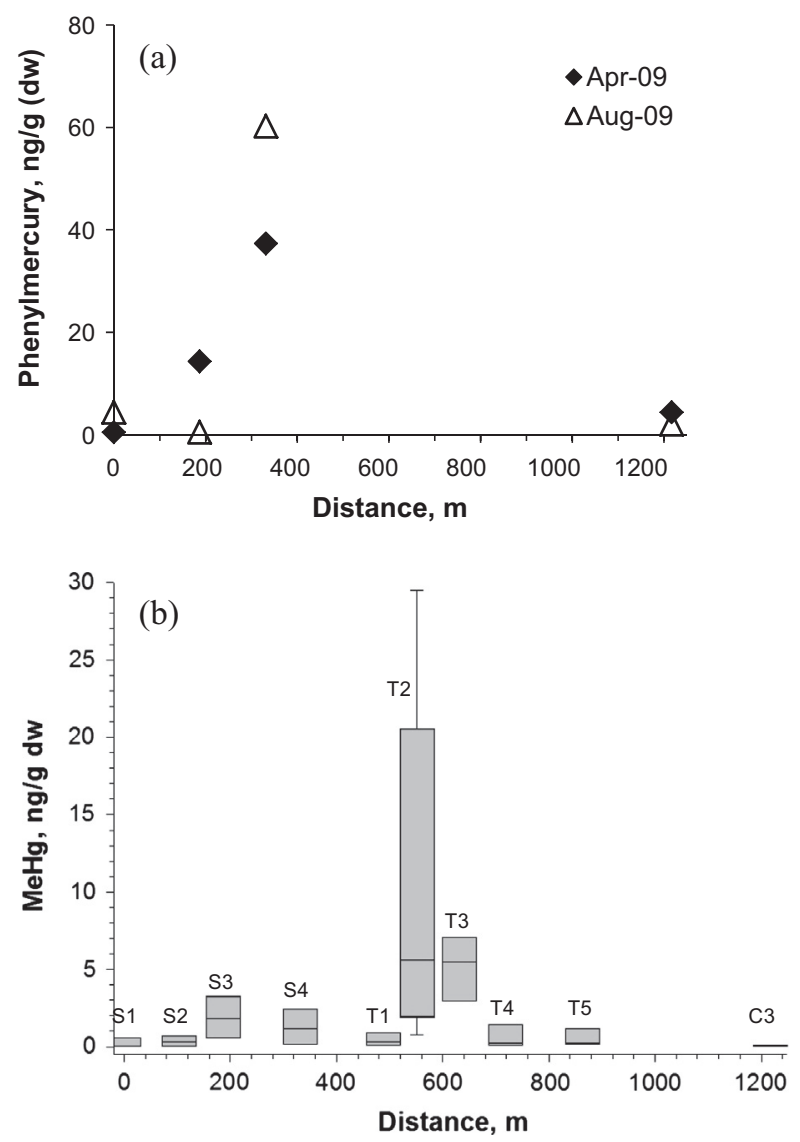

Fig. 4. (a) Phenylmercury in selected soil and sediment samples and (b) methylmercury concentrations (as $\mathrm{Hg}$ ) in soil and sediment samples from March 2008 to August 2009. Data are plotted as a function of distance from Site S1. Box and whisker plots show the $5-95 \%$ percentile range, median, and $25-75 \%$ percentiles ( $n=6-9$ for each site). All data are included in SI Table S3.

1968; Hintelmann et al., 1995), and no instances of in situ production have been documented.

Since the completion of the athletic field in 1929 (Duke University Library Archives; Kirschenfeld, 2009), the sod has not been replaced. Thus, the present-day soil contamination could be a legacy of $\mathrm{Hg}$-fungicides applied to turf grasses that have accumulated from previous decades. Soils to which $\mathrm{Hg}$-fungicides have been applied can retain $\mathrm{Hg}$ over long periods of time due to binding of $\mathrm{Hg}$ to soil organic matter and adsorption to soil particles (Aomine and Inoue, 1967). Furthermore, organo-Hg fungicides can degrade slowly over time to products such as inorganic $\mathrm{Hg}$ species (Kimura and Miller, 1964; Gilmour and Miller, 1973). The organo-Hg compounds that were applied to the soil likely decomposed over time, resulting in low but detectable concentrations of the original compound (up to $2 \%$ ).

The existence of $\mathrm{Hg}$ hotspots on the athletic field may be a result of spatially variable $\mathrm{Hg}$-fungicide applications and factors which influenced the loss of $\mathrm{Hg}$ from the soil. For example, processes such as the degradation of phenylmercury and the evasion of $\mathrm{Hg}$ species to the atmosphere can be influenced by factors such as soil microorganisms, water content, $\mathrm{Hg}$ chemical speciation, and $\mathrm{Hg}$ binding to soil components (Kimura and Miller, 1964).

\subsection{Fate of $\mathrm{Hg}$ downstream of the athletic field}

Wetland-type ecosystems have been identified as potential sites for elevated $\mathrm{MeHg}$ production, as they are regions with high rates of organic matter decomposition and sulfate-reducing conditions that are conducive to in situ $\mathrm{MeHg}$ production (St. 
Louis et al., 1994; Vaithiyanathan et al., 1996). Measurements of $\mathrm{MeHg}$ concentrations in soil increased from $\leqslant 4.7 \mathrm{ng} \mathrm{g}^{-1}(\mathrm{dw})$ in the campus catchment (S1-S4) to $0.6-30.6 \mathrm{ng} \mathrm{g}^{-1}$ (dw) in sediments obtained from the tributary to Sandy Creek (T1-T5) (Fig. 4b). The fraction of total $\mathrm{Hg}$ present as $\mathrm{MeHg}$ was as much as $9 \%$ at site $\mathrm{T} 4$. MeHg concentrations in the tributary spanned three orders of magnitude, indicating the presence of MeHg hotspots. AVS concentrations also increased from $<0.09 \mu \mathrm{mol} \mathrm{g}^{-1}$ (dw) in the campus catchment to $0.03-2.67 \mu \mathrm{mol} \mathrm{g}^{-1}$ (dw) in the tributary (T1-T5), suggesting that conditions were favorable for in situ sulfate reduction and $\mathrm{Hg}$ methylation (SI Fig. S2). The presence of MeHg hotspots may be due to spatial variations in reducing conditions, occurrence of methylating bacteria, organic matter, $\mathrm{Hg}$ chemical speciation, and $\mathrm{Hg}$ availability for bacterial methylation, all of which can influence $\mathrm{MeHg}$ production.

Within the stream-wetland, there could be additional sources of $\mathrm{Hg}$, such as vehicular exhaust and sediments that are transported to the study site via the main stem of Sandy Creek. However, water samples collected at sites C1 and C2 along the Creek contained $\leqslant 2.4 \mathrm{ng} \mathrm{L}^{-1} \mathrm{Hg}$, indicating that these sources of $\mathrm{Hg}$ were low relative to the campus runoff.

Although we observed relatively high levels of total $\mathrm{Hg}$ and $\mathrm{MeHg}$ in wetland sediments immediately downstream of the point of discharge of campus runoff, total $\mathrm{Hg}$ and $\mathrm{MeHg}$ were significantly reduced at downstream locations. This observed decrease in $\mathrm{MeHg}$ concentrations was likely influenced by the decrease in total $\mathrm{Hg}$ concentrations in both water and sediment downstream of the outfall pipe at site T1 (Figs. 2 and 3). A linear regression of the total solids concentration versus total $\mathrm{Hg}$ concentration was used to assess dilution and sedimentation of $\mathrm{Hg}$ along with particulate material while surface water concentrations of bromide, used as a conservative tracer for mixing between the tributary ("T" sites) and water from the main stem of Sandy Creek ("C" sites), were plotted versus the concentration of total filterable $\mathrm{Hg}$. Linear regressions performed on the normalized square root-transformed data indicated that: (1) bromide concentrations did not vary with filterable total $\mathrm{Hg}\left(r^{2}=0.005 ; p=0.80 ; n=17\right)$; and (2) the total solids concentrations in surface water were correlated with total $\mathrm{Hg}$ concentrations, although the correlation was not significant at the $95 \%$ confidence level $\left(r^{2}=0.45 ; p=0.07 ; n=8\right)$ (SI Fig. S3). The observed correlation between total solids and total $\mathrm{Hg}$ is consistent with previous studies of $\mathrm{Hg}$ transport in urban runoff and urbanized streams (Eckley and Branfireun, 2008; Brigham et al., 2009), and suggests that the decrease in $\mathrm{Hg}$ concentrations may be largely governed by the transport dynamics of Hg-bearing suspended particles (e.g., dilution, sedimentation).

\subsection{Hg mass balance}

The area of the athletic field $\left(0.028 \mathrm{~km}^{2}\right)$ was approximately $10 \%$ of the total area of the campus catchment $\left(0.255 \mathrm{~km}^{2}\right)$ (Mahi, 1994). The remaining $90 \%\left(0.227 \mathrm{~km}^{2}\right)$ contained a Hg background that could be derived from various sources including native geology, construction material, and atmospheric deposition. To assess the importance of the athletic field relative to the background with respect to the $\mathrm{Hg}$ concentrations in runoff during baseline flow, we performed a $\mathrm{Hg}$ mass balance in which the control volume was the campus catchment drainage system (SI Fig. S4). Inputs were calculated as mass transfer rates of $\mathrm{Hg}$ from: (i) the background using data from sites S1 and S2; and (ii) the athletic field using data from sites S3 and S4 (SI Table S4). The output was the $\mathrm{Hg}$ mass transfer rate at site $\mathrm{T} 1$. The difference between total inputs and the output was attributed to losses and/or additions due to processes such as resuspension which may occur within the drainage network (denoted as $m_{R}$ in the mass balance). The $\mathrm{Hg}$ mass balance in terms of mass transfer rate $(m)$ is represented by Eq. (1), where the subscript indicates inputs from the background and athletic field, output at $T 1$, and losses/additions due to processes occurring within the drainage network $(R)$ :

$m_{\text {background }}+m_{\text {field }} \pm m_{R}=m_{T 1}$

The mass transfer rates for the athletic field, background, and output at $T 1$ were calculated using Eq. (2):

$m_{x}=Q_{x} \cdot C_{x}$

where $m$ is the $\mathrm{Hg}$ mass transfer rate $\left(\mathrm{ng} \mathrm{s}^{-1}\right), Q$ is flow rate $\left(\mathrm{L} \mathrm{s}^{-1}\right)$, $C$ is the total $\mathrm{Hg}$ concentration (ng $\mathrm{L}^{-1}$ ), and the subsript $x$ denotes the athletic field, background, or the output at site T1, respectively. The total flow rate from the catchment $\left(Q_{T}\right)$ ranged from 0.95 to $1.76 \mathrm{~L} \mathrm{~s}^{-1}$ during the sampling period and was assumed to be directly proportional to the total area of the catchment $\left(A_{T}\right)$. Thus, $Q_{x}$ was calculated using Eq. (3):

$Q_{x}=Q_{T} \cdot A_{x} / A_{T}$

Based on these calculations (SI Table S4), the $\mathrm{Hg}$ mass transfer rate from the athletic field (12.8-21.7 $\mathrm{ng} \mathrm{s}^{-1}$ ) exceeded background levels (3.6-26.5 $\mathrm{ng} \mathrm{s}^{-1}$ ) on two out of three sampling events. $\mathrm{Hg}$ from the athletic field contributed approximately $56-78 \%$ of the total $\mathrm{Hg}$ input to the drainage network, compared to $24-44 \%$ from other sources such as atmospheric deposition, construction material, and native geology. The $\mathrm{Hg}$ flux $(J)$ for the inputs were calculated using Eq. (4):

$J_{x}=\left(Q_{x} \cdot C_{x}\right) / A_{x}$

The $\mathrm{Hg}$ flux from the athletic field ranged from 465.5 to $787.5 \mathrm{ng} \mathrm{km}^{-2} \mathrm{~s}^{-1}$, and consistently exceeded the background flux (15.9-72.6 $\mathrm{ng} \mathrm{km}^{-2} \mathrm{~s}^{-1}$ ) by an order of magnitude (SI Table S4). Thus, despite its relatively small area, the athletic field soil appeared to be the larger $\mathrm{Hg}$ source compared to the background.

Limitations of our calculations include the small sample size ( $n=8-10$ for each site), the scaling of flow rate based on percentage land area within the catchment, and the simplification of $\mathrm{Hg}$ inputs into "background", the athletic field, and processes occurring within the drainage network $(R)$. We note, however, that the mass balance calculations are intended only to provide a relative estimate of the $\mathrm{Hg}$ mass transfer rates derived from the athletic field and background. The mass transfer rates presented here likely represent the lower limit of $\mathrm{Hg}$ transport from the catchment, as samples were obtained during base flow conditions when flow rate (Q) as well as erosion, particle transport and scouring of settled material within pipes were minimal, resulting in lower Hg concentrations $(C)$ at sampling locations.

\section{Implications and significance}

The issue of contamination from the historical application of $\mathrm{Hg}$ anti-fungal compounds is not isolated to the Duke University athletic fields. For example, $\mathrm{Hg}$-contaminated soil in golf courses and Hg-contaminated fish in golf course lakes have been previously documented (Koirtyohann et al., 1974; Frank, 1981; Matthews et al., 1995), and instances of Hg-contaminated groundwater in a rapidly urbanizing New Jersey watershed have been linked to the use of $\mathrm{Hg}$-fungicides in regions where agriculture was the primary land use (Barringer et al., 2013).

$\mathrm{Hg}$ anti-fungal agents were broadly used in fertilizers, pesticides, and seed treatments (e.g., Panogen, Phelam, Murfixtan (FAO)) in the US from 1917 to 1995 (US EPA b; Murphy and Aucott, 1999). Approximately 3203 metric tons of $\mathrm{Hg}$ were used for agricultural applications from 1921 to 1990 , with the total estimated acreage ranging from 6.5 million acres (1900-1901) to 5.3 million (1981-1990) across the US (Murphy and Aucott, 1999). Hg was also used as an anti-fungal preservative in paints, with approximately 
7200 metric tons used in paint manufacturing from 1941 to 1990 (US Bureau of Mines (1932-1993)). Thus, soils and surfaces contaminated by Hg-fungicides are likely widespread, and the exact extent to which regions in the US are contaminated is unknown. According to the US EPA, a large portion of the total $\mathrm{Hg}$ loading to water bodies in the US is from unknown sources (US EPA, 2004). Surface runoff from soils contaminated by legacy $\mathrm{Hg}$-fungicides may well be a contributor to the $\mathrm{Hg}$ contamination to these waters.

While neither Sandy Creek nor Jordan Lake is currently under a specific fish mercury advisory, a statewide advisory is in effect for North Carolina (US EPA c). Despite reduced total Hg and MeHg concentrations at the furthest downstream sampling location, low level $\mathrm{Hg}$ inputs to the Jordan Lake reservoir over time may eventually lead to $\mathrm{MeHg}$ accumulation in fish above the US EPA action level. The mitigation of non-point source $\mathrm{Hg}$ loading and subsequent $\mathrm{MeHg}$ bioaccumulation in aquatic ecosystems are problematic, and improved frequency and increased extent of monitoring networks are warranted to address these issues. Special attention should be paid to watersheds in which land was historically used for agricultural or recreational purposes, particularly those which have been urbanized. Urbanization may influence the emergence of contaminants in surface runoff through the mobilization of soil and sediment and the production of larger volumes of surface runoff generated due to increased area of impervious surfaces.

Lastly, future studies could examine the environmental fate and transport of historically applied $\mathrm{Hg}$ anti-fungal compounds, such as phenylmercury, ethylmercury, methylmercury, methoxyethylmercury and ethoxymethylmercury compounds (FAO).

\section{Acknowledgements}

We would like to thank P. Canning, N. Polishchuk, J. Bailoo, A. Gondikas, W. Willis, and the Duke University Facilities Management Department for assistance with field sampling, Y. Yin for assistance with phenylmercury analysis, and J. Bailoo for assistance with statistical analyses.

\section{Appendix A. Supplementary material}

This section contains descriptions of analytical methods for methylmercury and phenylmercury, site data, and mass balance calculations. Supplementary data associated with this article can be found, in the online version, at http://dx.doi.org/10.1016/ j.chemosphere.2014.12.038.

\section{References}

Allen, H.E., Fu, G.M., Deng, B.L., 1993. Analysis of acid-volatile sulfide (Avs) and simultaneously extracted metals (Sem) for the estimation of potential toxicity in aquatic sediments. Environ. Toxicol. Chem. 12 (8), 1441-1453.

Aomine, S., Inoue, K., 1967. Retention of mercury by soils. II. Adsorption of phenylmercuric acetate by soil colloids. Soil Sci. Plant Nutr. 13 (6), 195-200.

Barringer, J.L., Szabo, Z., Reilly, P.A., Riskin, M.L., 2013. Variable contributions of mercury from groundwater to a first-order urban coastal plain stream in New Jersey, USA. Water Air Soil Pollut. 224.

Bloom, N.S., Fitzgerald, W.F., 1988. Determination of volatile mercury species at the picogram level by low-temperature gas chromatography with cold-vapour atomic fluorescence detection. Anal. Chim. Acta 208, 151-161.

Bloom, N.S., Colman, J.A., Barber, L., 1997. Artifact formation of methyl mercury during aqueous distillation and alternative techniques for the extraction of methyl mercury from environmental samples. Fresen. J. Anal. Chem. 358, 371-377.

Brigham, M.E., Wentz, D.A., Aiken, G., Krabbenhoft, D.P., 2009. Mercury cycling in stream ecosystems. 1. Water column chemistry and transport. Environ. Sci. Technol. 43, 2720-2725.

Cline, J.D., 1969. Spectrophotometric determination of hydrogen sulfide in natural waters. Limnol. Oceanogr. 14 (3), 454-458.

Driscoll, C.T., Holsapple, J., Schofield, C.L., Miunson, R., 1998. The chemistry and transport of mercury in a small wetland in the Adirondack region of New York, USA. Biogeochemistry 40, 137-146.

Duke University Library Archives. Duke History: Wallace Wade Stadium. <http:/ library.duke.edu/uarchives/history/histnotes/wade_stadium.html> accessed 07.11.13).
Eaton, A.D., Clesceri, L.S., Rice, E.W., Greenberg, A.E., Franson, M.H., 2005. Standard Methods for the Examination of Water and Wastewater, 21 ed. American Public Health Association.

Eckley, C.S., Branfireun, B.A., 2008. Mercury mobilization in urban stormwater runoff. Sci. Total Environ. 403, 164-177.

FAO Food and Agricultural Organization FAOSTAT database (<http://faostat.fao.org/ site/424/default.aspx\#ancor> 17.11.10).

Fitzgerald, W.F., Mason, R.P., Vandal, G.M., 1991. Atmospheric cycling and air-water exchange of mercury over midcontinental lacustrine regions. Water Air Soil Pollut. 56, 745-767.

Frank, R., 1981. Distribution of mercury residues from the use of mercurial fungicides on golf course greens. Can. J. Soil Sci. 61 (3), 525-527.

Gilmour, J.T., Miller, M.S., 1973. Fate of a mercuric-mercurous chloride fungicide added to turfgrass. J. Environ. Qual. 2 (1), 145-148.

Hintelmann, H., Wilken, R.D., 1993. The analysis of organic mercury compounds using liquid chromatography with on-line atomic fluorescence sprectrometric detection. Appl. Organomet. Chem. 7, 173-180.

Hintelmann, H., Hempel, M., Wilken, R.D., 1995. Observations of unusual organic mercury species in soils and sediments of industrially contaminated sites. Environ. Sci. Technol. 29, 1845-1850.

Kimura, Y., Miller, V.L., 1964. The degradation of organomercury fungicides in soil. J. Agric. Food Chem. 12 (3), 253-257.

King, J.K., Saunders, F.M., Lee, R.F., Jahnke, R.A., 1999. Coupling mercury methylation rates to sulfate reduction rates in marine sediments. Environ. Toxicol. Chem. 18 (7), 1362-1369.

Kirschenfeld, A., 2009. Any Given Wednesday. Duke Magazine, vol. 95. Duke University, Durham.

Koirtyohann, S.R., Meers, R., Graham, L.K., 1974. Mercury levels in fishes from some Missouri lakes with and without known mercury pollution. Environ. Res. 8, 1-11.

Krabbenhoft, D.P., Benoit, J.M., Babiarz, C.L., Hurley, J.P., Andren, A.W., 1995 Mercury cycling in the Allequash Creek Watershed, Northern Wisconsin. Water Air Soil Pollut. 80, 425-433.

Mahi, H., 1994. Stormwater management and modeling at Duke University. OCLC Number 31913456.

Matthews, S.L., McCraken, I.R., Lonergan, G., 1995. Mercury contamination of golf courses due to pesticide use. Bull. Environ. Contam. Toxicol. 55, 390-397.

Murphy, E.A., Aucott, M., 1999. A methodology to assess the amounts of pesticidal mercury used historically in New Jersey. J. Soil Contam. 8 (1), 131-148.

Richardson, C., Flanagan, N., Ho, M., Pahl, J.W., 2011. Integrated stream and wetland restoration: a watershed approach to improved water quality on the landscape. Ecol. Eng. 37 (1), 25-39.

Sorensen, J.A., Glass, G.E., Schmidt, K.W., Huber, J.K., Rapp, G.R., 1990. Airborne mercury deposition and watershed characteristics in relation to mercury concentrations in water sediments, plankton, and fish of eighty northern Minnesota Lakes. Environ. Sci. Technol. 24, 1716-1727.

St. Louis, V.L., Rudd, J.W.M., Kelly, C.A., Beaty, K.G., Bloom, N.S., Flett, R.J., 1994. Importance of wetlands as sources of methyl mercury to boreal forest ecosystems. Can. J. Fish Aquat. Sci. 51, 1056-1076.

Sumino, K., 1968. Analysis of organic mercury compounds by gas chromatography. II. Determination of organic mercury compounds in various samples. Kobe J. Med. Sci. 14 (2), 131-148.

US Bureau of Mines, (1932-1993) (<http://minerals.usgs.gov/minerals/pubs/ usbmmyb.html> 07.11.13)

US EPA, 1996. EPA method 1669: sampling ambient water for trace metals at EPA water quality criteria levels, <http://www.epa.gov/caddis/pdf/Metals Sampling_EPA_method_1669.pdf $>$ Accessed December 26, 2014.

US EPA, 1997. Mercury study report to congress (<http://www.epa.gov/mercury/ report.htm> accessed 07.11.13).

US EPA, 1998. EPA method 1630: methyl mercury in water by distillation, aqueous ethylation, purge and trap, and cold vapor atomic fluorescence spectrometry, <http://nepis.epa.gov> Accessed December 26, 2014.

US EPA, 1998. EPA method 7473: mercury in solids and solutions by thermal decomposition, amalgamation, and atomic absorption spectrophotometry.

US EPA, 2002. EPA method 1631 revision E: mercury in water by oxidation, purge and trap, and cold vapor atomic fluorescence spectromtery, <http://water.epa.gov/ scitech/methods/cwa/metals/mercury/upload/2007_07_10_methods_method_ mercury_1631.pdf> Accessed December 26, 2014

US EPA, 2004. National Water Quality Inventory: Report to Congress. Reporting Cycle 2004 (<http://www.epa.gov/305b/> accessed 07.11.13).

US EPA a, Introduction to the Clean Water Act Module (<http://www.epa.gov/ owow/watershed/wacademy/acad2000/cwa/index.htm> accessed 07.11.13).

US EPA $b$, Table of products that may contain mercury and recommended management options (<http://www.epa.gov/mercury/mgmt_options.html> accessed 07.11.13).

US EPA c, National Listing of Fish Advisories. <http://water.epa.gov/scitech/ swguidance/fishshellfish/fishadvisories/> accessed 07.11.13.

US EPA d, Mercury and Air Toxics Standards - Cleaner Power Plants (<http:// www.epa.gov/airquality/powerplanttoxics/index.html> accessed 07.11.13).

US Geological Survey, National Geochemical Database (<http://tin.er.usgs.gov/ geochem/doc/home.htm> accessed 07.11.13).

Vaithiyanathan, P., Richardson, C.J., Kavanaugh, R., Craft, C.B., Barkay, T., 1996. Relationships of eutrophication to the distribution of mercury and to the potential for methylmercury production in the peat soils of the everglades. Environ. Sci. Technol. 30 (8), 2591-2597. 